Original research article

\title{
Finances of the citizens of the Czech Republic spent on sports activities to prevent and treat cardiovascular diseases
}

\author{
Radka Prokešová ${ }^{1}{ }^{*}$, Valérie Tóthová ${ }^{2}$, Věra Olišarová ${ }^{2}$, Lenka Šedová ${ }^{2}$, Ivana Chloubová ${ }^{2}$, \\ Marie Trešlová ${ }^{2}$, Sylva Bártlová ${ }^{2}$, Helena Michálková ${ }^{2}$ \\ ${ }^{1}$ University of South Bohemia in České Budějovice, Faculty of Health and Social Sciences, Institute of Humanities in Nursing Professions, \\ České Budějovice, Czech Republic \\ ${ }^{2}$ University of South Bohemia in České Budějovice, Faculty of Health and Social Sciences, Institute of Nursing, Midwifery and Emergency Care, \\ České Budějovice, Czech Republic
}

\begin{abstract}
Sports activities are important factors in the prevention of the incidence and development of cardiovascular diseases. The goal of this article was to find out, describe and assess the relationship of the finances spent on sports activities to prevent and treat cardiovascular diseases to education, employment and marital status. The research was carried out using the quantitative research strategy (a non-standardized questionnaire). The sample group (1,992 people from the Czech Republic - 937 men and 1,055 women) had the typical structure of the Czech population and was representative from the point of view of regions, gender and age. The results showed statistically significant relationships between the money spent monthly on sports activities to prevent and treat cardiovascular diseases. Respondents with a higher level of education invested more money in sports activities than those with a lower level of education. Employed and self-employed people invested more money in sports activities than pensioners. Single people invest more in sports activities; the widowed invest less, which could be caused by the fact that the Czech Republic is undergoing a change in the population structure. These facts provide medical workers with valuable information that can be used in practice. This information can help to make medical consulting regarding sports activities more efficient and so prevent cardiovascular diseases. It also points out the necessity of an individual approach regarding practical recommendations in relation to education, employment and marital status.
\end{abstract}

Keywords: Cardiovascular disease; Education; Employment; Finances; Marital status; Sports activities

\section{Introduction}

Sports activities are included among the significant factors that affect the incidence and development of cardiovascular diseases (Commission of the European Communities, 2007). The basis of the prevention and treatment of cardiovascular diseases is restricting health risks in lifestyle because this can prevent up to $80 \%$ of untimely deaths due to cardiovascular diseases (National Institute for Health and Care Excellence, 2017; National Institute of Public Health, 2017). According to a number of studies (Chaloupka et al., 2003; Pina et al., 2003; Pirnerová, 2017), regular activities help to decrease the incidence and development of cardiovascular diseases, strengthen the nervous system, increase stress resistance, strengthen vascular muscles and prevent hypertension. The White Book of the Commission of the European Communities (2007) states that insufficient physical activity increases the incidence of overweight, obesity and a number of chronic diseases, such as cardiovascular diseases and diabetes, which decrease the quality of life, threaten life and burden medical and economic budgets.

The effect of sports activities is not only positive regarding the primary prevention of cardiovascular diseases, but also regarding the secondary preventative measures in people who already suffer from cardiovascular disease (Linhart, 2016). Significant findings regarding sports activities and the total risk of cardiovascular diseases (mainly hypertension and hypercholesterolemia) were published by a collective of authors in the 1970s (Paffenbarger et al., 1978). The positives of regular physical activities include the improvement of cardio-respiratory functions, maintaining the optimal body weight as well as good mental health. Physical activities help to postpone the incidence of atherosclerosis as well as type 2 diabetes and depressive disturbances. Physical activities should be recommended by a cardiologist and adjusted to a patient's cardio-respiratory system and locomotive system, including a patient's motivation for physical activities.

\footnotetext{
* Author for correspondence: Radka Prokešová, University of South Bohemia in České Budějovice, Faculty of Health and Social Sciences, Institute of Humanities in Nursing Professions, J. Boreckého 27, 37011 České Budějovice, Czech Republic; e-mail: rprokes@zsf.jcu.cz; http://doi.org/10.32725/kont.2019.033 
Almost all people, regardless of their illness, can be motivated to perform common physical activities, such as walking, gardening or housework (Rosolová et al., 2013). The report on the health of the population of the Czech Republic from 2014 was based on the results of the study regarding the physical activities of adults and states that $32 \%$ of adults have a low level of physical activity, $21 \%$ have a medium level and $46 \%$ have a high level. Men had a 1.4x higher probability of being physically active compared to women (Antošová et al., 2014). In the Czech Republic, cardiovascular diseases are the most frequent cause of death (women $-50 \%$ of all deaths; men $42 \%$ ). The standardized level of mortality regarding age is $60 \%$ higher than the average in the EU (OECD/European Observatory on Health Systems and Policies, 2017). Due to these facts, it is possible to say that more than $35 \%$ of the total disease burden is caused by behavioural risk factors (disease burden is the indicator combining morbidity and mortality). According to the Institute for Global Health Data Exchange (2017), the behavioural risk factors include risky eating habits (18\%), smoking (13\%), alcohol consumption (4\%) and insufficient physical activities (3\%).

Cardiovascular diseases not only decrease the quality of life and are life-threatening, they also burden healthcare and family budgets (lost profits, decreased work activity, decreased applicability on the labour market). Diseases of the circulatory system are included in the most frequent causes of hospitalization despite a significant decrease in comparison to previous years (Medical statistics, 2016). In 2016, there were 298.5 thousand hospitalizations, 46.3 thousand cases of work incapacities and 38.6 thousand people in the Czech Republic drew disability pension at the end of the year (Medical statistics, 2017). Medical costs for cardiovascular diseases in the Czech Republic are usually covered by public health insurance (Revue for Social Policy and Research, 2018). Other economic aspects regarding the prevention and treatment of cardiovascular diseases are personal finances. From the point of view of the prevention of cardiovascular diseases, they are mainly costs related to lifestyle, i.e. costs for sports activities, consulting regarding lifestyle etc. This article is related to the project supported by the programme project of the Ministry of Health of the Czech Republic, reg. no. 15-31000A, entitled "Intervention Procedures in Preventative Cardiology". Its goal was to find, describe and assess the relationship between financial costs and sports activities of the people of the Czech Republic and their education, employment and marital status, where the areas is related to the prevention of cardiovascular diseases.

\section{Materials and methods}

This research was carried out using the quantitative research strategy. We used a non-standardized questionnaire to learn the amount of monthly financial costs spent on sports activities regarding the prevention and treatment of cardiovascular diseases. We used a three-level scale ( 0 up to 500 CZK, 501 up to $1,000 \mathrm{CZK}$ and more than $1,000 \mathrm{CZK}$ ) which was related to their education, employment and marital status. At the beginning, the scale had six levels, but the statistical processing re-categorized the four highest financial costs into one category, i.e. more than $1,000 \mathrm{CZK}$. The sample group included 1,992 citizens of the Czech Republic (937 men and 1,055 women). Its structure responded to the structure of all citizens of the Czech Republic and is representative regarding regions, gender and age. The collection of data was carried out in the Czech Re- public in 2016. The gained data were processed by the descriptive and analytical statistics using the statistical application of SASD 1.4.12 (Statistical Analysis of Social Data) and SPSS. We also processed the 1st classification degree and contingency tables of selected indicators in the 2 nd classification degree. In the 1st classification degree, we calculated the absolute and relative numbers, mode, median, average, variance and standard deviation. For every indicator, we calculated the estimated variance and standard deviation, span and interval estimate of the average value of 0.05 and interval estimate of the variance of 0.05 . For the calculation of the level of independence of selected indicators, we calculated the Wallis, Spearman and correlation coefficient. We also applied the $\chi^{2}$ of the good accord. In this case, we applied the Yates correction due to the insufficient number of monitorings. Finally we calculated the test of independence on the level of significance of $\alpha=0.05$, $\alpha=0.01, \alpha=0.001$.

\section{Results}

This research was carried out using a non-standardized questionnaire to find out the average monthly finances spent on sports activities by $\mathrm{Czech}$ citizens regarding the prevention and treatment of cardiovascular diseases. Out of the total 1,992 respondents, $78.3 \%$ spent less than 500 CZK, $14.5 \%$ spent 501 up to $1000 \mathrm{CZK}$ and $7.2 \%$ spent more than 1,000 CZK.

We used the non-standardized questionnaire to find out the relationship between the monthly financial amount spent on sports activities and the selected sociodemographic indicators (education, employment and marital status). This relationship is shown in Table 1.

\begin{tabular}{|c|c|c|c|}
\hline Monitored relationship & $p$ & $\chi^{2}$ & df \\
\hline relationship to education & $<0.001$ & 92,618 & 8 \\
\hline relationship to employment & $<0.001$ & 147,821 & 10 \\
\hline relationship to marital status & $<0.001$ & 46,282 & 8 \\
\hline
\end{tabular}

The respondents were divided by the achieved level of education: basic education, vocational school graduates, secondary/high school graduates, higher vocational education and university education. Out of the total 162 respondents with basic education, 149 invested less than 500 CZK monthly on sports activities, 10 invested between 501 and 1,000 CZK, and 3 invested more than 1,000 CZK. 630 respondents with secondary education without GCSE's invested on average 500 CZK, 76 invested between 501 and 1,000 CZK, and 29 invested 1,000 CZK and more. 680 respondents graduated from secondary school with GCSE's. 509 invested up to $500 \mathrm{CZK}$, 111 invested between 501 and 1,000 CZK, and 60 invested more than 1,000 CZK. 103 respondents graduated from a higher vocational school. 75 invested up to 500 CZK, 18 invested between 501 and 1,000 CZK, and 10 invested more than 1,000 CZK. Out of the total 312 respondents, 197 university educated respondents invested the average monthly amount, 74 invested between 501 and 1,000 CZK, and 41 invested more than $1,000 \mathrm{CZK}$. The results are shown in Chart 1 . 


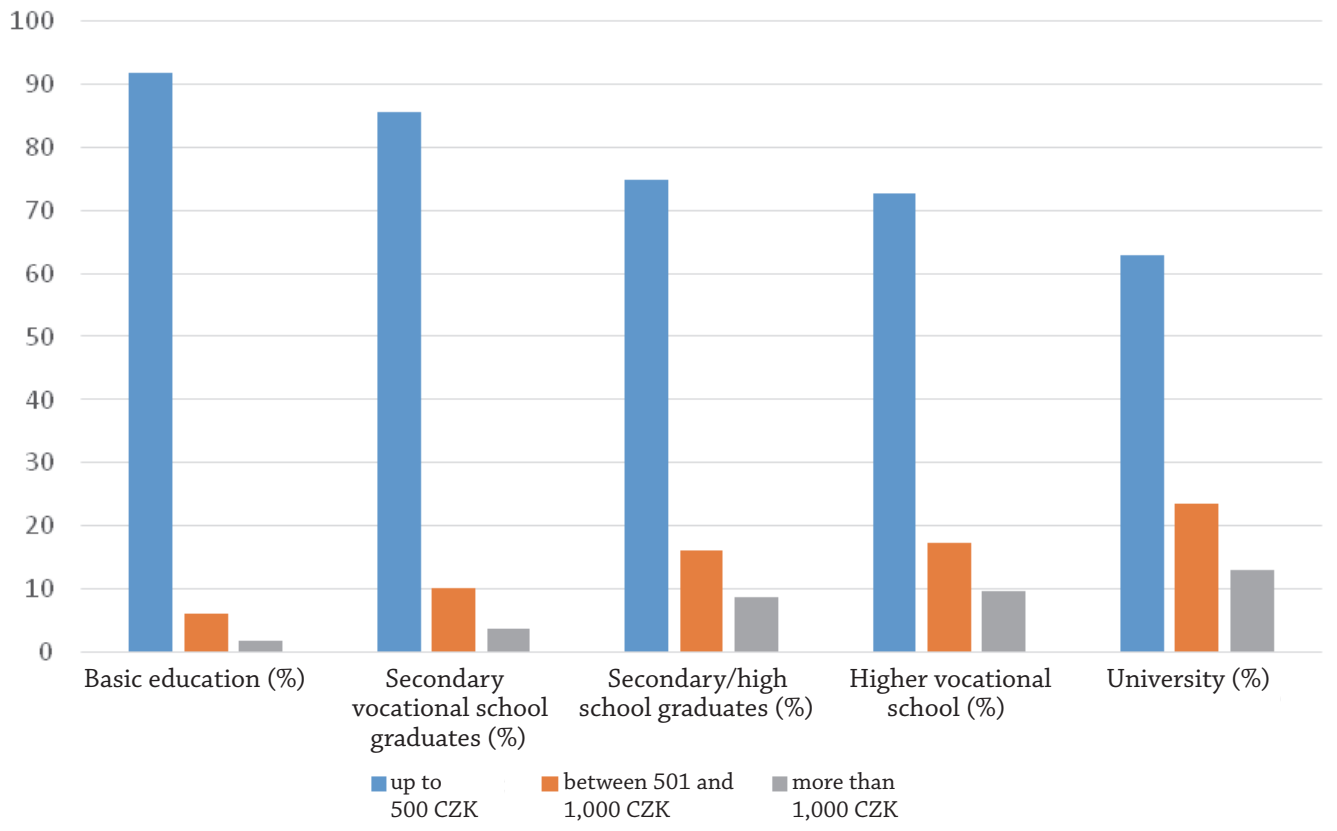

Chart 1. Average monthly costs invested in sports activities in relation to education

The results of this research show a statistically significant relationship between the average monthly finances and education. Regarding the statistically significant relationship between education and average finances invested in sports activities at the level of significance $p<0.001$, we learned that respondents with a higher level of education invested more than those with a lower level.

While finding out the relationship between the average finances invested in sports activities and employment, the respondents were divided into categories: employees, entrepreneurs, pensioners, disabled pensioners, people who had been unemployed longer than 6 months and others. Out of the total 965 employed respondents, 695 invested up to 500 CZK, 182 invested between 501 and 1,000 CZK, and 88 invested more than 1,000 CZK. Out of the 211 entrepreneurs, 130 invested up to $500 \mathrm{CZK}, 46$ invested between 501 and 1,000 CZK, and 35 invested more than 1,000 CZK. Out of 674 pensioners, 615 invested up to 500 CZK, 46 invested between 501 and 1,000 CZK, and 13 invested more than $1,000 \mathrm{CZK}$. Out of 92 disabled pensioners, 83 invested up to $500 \mathrm{CZK}, 6$ invested between 501 and 1,000 CZK, and 3 invested more than $1,000 \mathrm{CZK}$. Out of the total 38 respondents who had been unemployed longer than 6 months, 31 invested less than 500 CZK, 6 invested between 501 and 1,000 CZK, and only 1 invested more than 1,000 CZK. Out of 12 respondents whose employment could not be included in any category (others), 6 invested up to 500 CZK, 3 invested between 501 and 1,000 CZK, and 3 also invested more than 1,000 CZK. These results are shown in Chart 2.

The results of this research showed a statistically significant relationship between the average monthly finances and employment. The results show that employees and entrepreneurs invest in sports activities more than pensioners and disabled pensioners.

Regarding marital status, we divided the respondents into single, married, divorced, widowed and non-married partners. Out of 129 single respondents, 82 invested up to $500 \mathrm{CZK}$,
29 invested between 501 and 1,000 CZK, and 18 invested more than 1,000 CZK. Out of 1,197 married respondents, 925 invested up to $500 \mathrm{CZK}, 187$ invested between 501 and $1,000 \mathrm{CZK}$, and 85 invested more than 1,000 CZK. Out of 256 divorced respondents, 195 invested up to $500 \mathrm{CZK}, 38$ invested between 501 and 1,000 CZK, and 23 invested more than 1,000 CZK. Out of 309 widowed respondents, 279 invested up to $500 \mathrm{CZK}, 21$ invested between 501 and 1,000 CZK, and 9 invested more than 1,000 CZK. Out of 101 non-married partners, 79 invested up to 500 CZK, 14 invested between 501 and 1,000 CZK, and 8 invested more than 1,000 CZK. The results are shown in Chart 3.

The results of this research showed a statistically significant relationship between the average monthly finances and marital status. At the level of significance of $p<0.001$, the results show that single people invest more and the widowed invest less.

\section{Discussion}

The results of the research correspond with the results of the marketing research carried out on 1,120 respondents by Česká Spořitelna and the Kantar CZ research agency (Řezníčková, 2018). Their results show that a person who performs sports activities at least once a week spends more than 4,600 CZK per year on them. On the other hand, Czech health insurance companies paid out 25.4 billion CZK in the monitored period for the treatment of heart attacks, strokes and other cardiovascular diseases. Average costs of health insurance companies, according to the Czech Statistical Office (2018b), for one man suffering from cardiovascular disease in 2016 are more than 2,700 CZK (and 600 CZK lower for one woman). The EU statistics show much higher costs. The estimated costs of the EU for cardiovascular diseases are 169 trillion Euros per year. This means that the total annual costs are $372 €$ per capita (European Heart Health Charter), which is 9,625 CZK per capita 


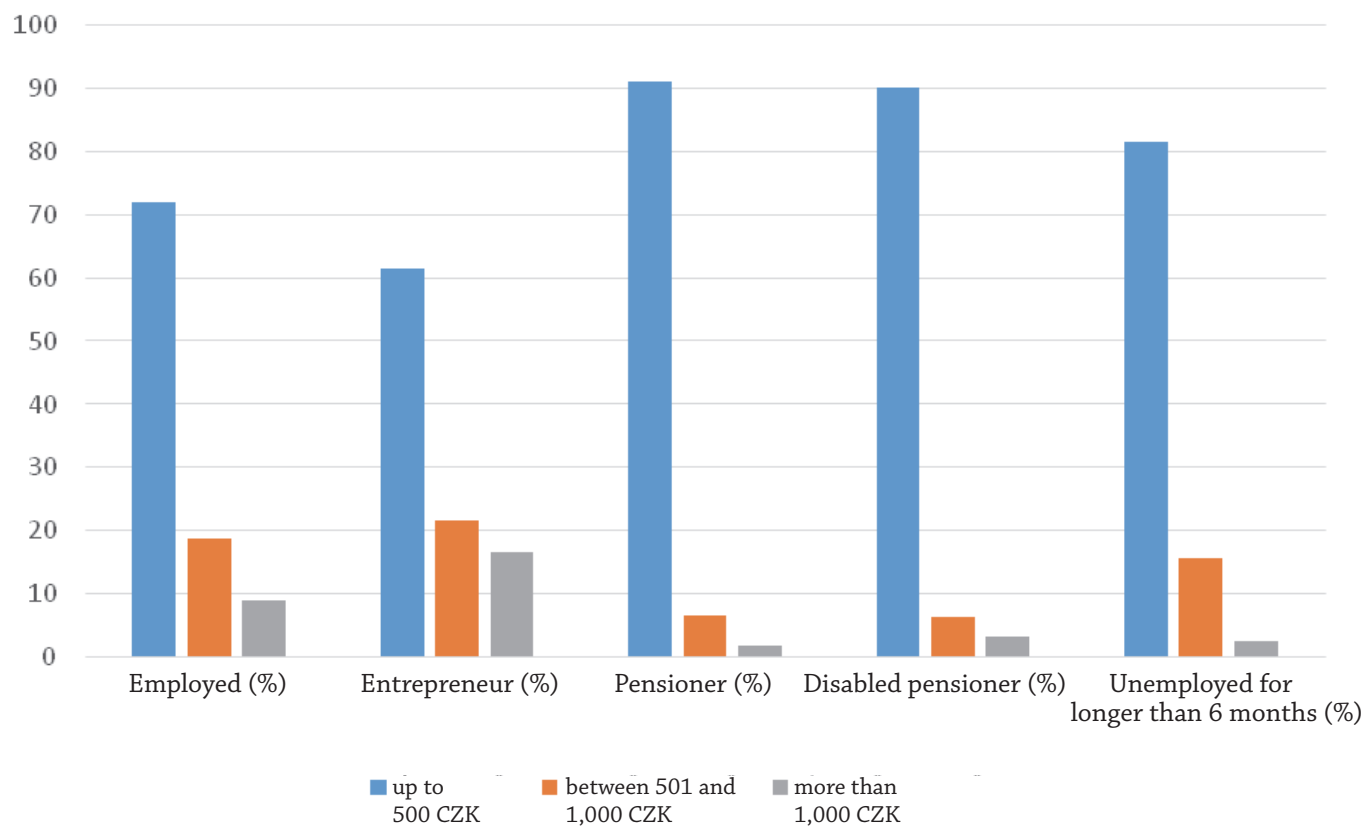

Chart 2. Average monthly costs invested in sports activities in relation to employment

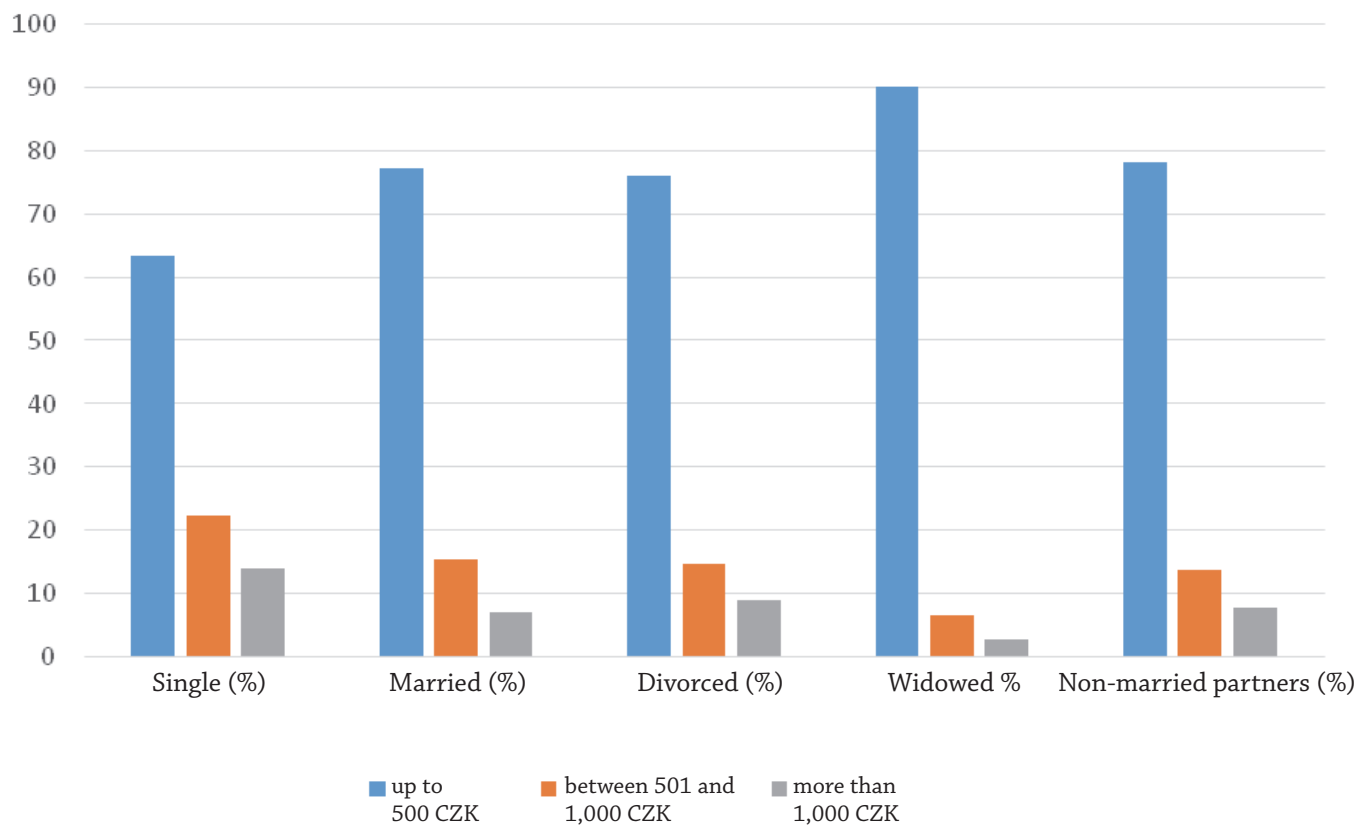

Chart 3. Average monthly costs invested in sports activities in relation to marital status

(Czech National Bank, 2018). In the future, this economic aspect should influence the pressure on decreasing risks, especially regarding the primary prevention of cardiovascular diseases. According to the WHO (2007), in practice this means a greater motivation for the decrease of fat and salt intake intake from food and an increase of fruit and vegetable intake (incl. pulses). From the point of view of sports activities, it means motivation for at least mild physical activity for 30 minutes a day. We should not neglect education on weight loss for people who are overweight or obese, where it is necessary to pay attention to the correct combination of diet change and sports activities. It is also necessary to be careful with alcohol consumption. A positive impact of correctly chosen preventative activities regarding health, economic and social spectre has been confirmed by Piepoli et al. (2016). Makris et al. (2012) base their conclusions on the results of international research, which show that only a few doctors (cardiovascular surgeons in this research) provide their patients with the information on correct physical activities and ask them to keep a diary of their daily physical activities. 
Similar results have also been confirmed by Olišarová et al. (2016). They show that in $51.2 \%$ of cases doctors always, often or sometimes spoke about changes in physical activities with their patients who were $40+$, whereas nurses only did this in $34.6 \%$ of cases. Systematic guidance with non-pharmacological interventions has a positive effect on patients' total health condition, helps to make treatment more efficient and ensures motivation for maintaining long-term lifestyle changes. Recommended activities can be divided into two groups - aerobic and anaerobic. Both groups are important for the maintenance and improvement of cardio-respiratory processes, but it is always important to consult them with an expert.

In 1992, the American Heart Association recognized physical inactivity as a risk factor of cardiovascular diseases. The results of the meta-analyses (Spencer et al., 2016) from 1995 to 2007 recommend being mildly physically active for 150 minutes per week or intensively active for 75 minutes (at least 10 minutes per day). The meta-analysis published by Sattelmair et al. (2011) shows that physical activity helps to decrease the risk of cardiovascular diseases (a larger association among women than men).

It is necessary to mention that the number of longitudinal studies are limited by the application of gained results, e.g. they do not respect variables such as the socio-economic status, or they are carried out on a homogenous sample group, e.g. Caucasians (Sattelmairet al., 2011). Physical activity cannot be perceived as an explanatory risk factor. As mentioned in the conclusions of the Canadian study of INTERHEART, mild or medium physical activities regarding both genders are associated with a decrease of cardiovascular risk. Physical activity is a variable independent of other risk factors, such as overweight, obesity, diabetes, dyslipidemia or hypertension. There are randomized controlled studies (Dunn et al., 1997; Sattelmair et al., 2011) which deal with causality. Dunn et al. (1997) assessed interventions regarding physical activities in healthy men and women who are in a sitting position most of the day. After six months, their cardio-respiratory abilities were improved and the coronary risk calculated by the SCORE was decreased. Tully et al. (2005) proved the improvement of cardio-respiratory functions and a decrease in the total score of the cardiovascular risk (SCORE) after 12 weeks in respondents between 50 and 65 years. Physical activity should be included in everyday life as much as possible at every age. As stated by Machová et al. (2016), physical activities are a necessary and most natural way to maintain and strengthen normal physiological functions. Nevertheless, there are many barriers to performing physical activities, such as socio-economic factors.

This research proved statistically significant relationships between the average monthly spend on sports activities and education. Respondents with a higher level of education invested more money in physical activities than respondents with a lower level of education. This result is related to the fact that in 2016 the percentage of people with a higher level of education was higher in relation to average salary than people with a lower level of education (Czech Statistical Office, 2016a).

This result also corresponds with the results of the research carried out by Česká Spořitelna and the Kantar CZ research agency (Řezníčková, 2018), which proved that people with university education used health insurance coverage or benefits from their employer for sports activities. Regarding sports activities, health literacy is important, which is mentioned by Levin-Zamir et al. (2016) in relation to education. We opine that these findings can directly affect nursing interventions, where it is necessary to select convenient educational activities and not forget patients' feedback.
This research also proved statistically significant relationships between the average monthly spend on sports activities and employment. Employed respondents and entrepreneurs invested more in sports activities than pensioners and disabled pensioners. The main reason was income. The average gross wage was 29,320 CZK (Czech Statistical Office, 2016c), whereas the pension was 11,475 CZK (Czech Statistical Office, 2016b). Another economic reason of employed respondents can be the effort to maintain good physical and psychological condition because drawing sickness insurance can affect people with a higher income, which is globally reflected in the trend of decreasing the number of sick days (Česko v datech, 2018). Supporting employees in the care of their health by various benefits, such as financial contributions for sports activities or preventative care are a very positive part in the previously mentioned result (Centers for Disease Control and Prevention, 2018).

This research also proved statistically significant relationships between the average monthly spend on sports activities and marital status. According to the research results, single respondents invested more in sports activities than the widowed. In the Czech Republic, the population structure is changing. There are continuously more single people and fewer married people, which could result in the fact that single people invest more in sports activities and the widowed less (Czech Statistical Office, 2018a). Some studies point out a decrease in physical activities in married people (Hull et al., 2010; Schoeppe et al., 2018).

\section{Conclusions}

The results of the research have shown statistically significant relationships between the average monthly costs for sports activities regarding the prevention and treatment of cardiovascular diseases and education, employment and marital status.

This research proved statistically significant relationships between the average monthly spend on sports activities and education. Respondents with a higher level of education invested more money in physical activities than respondents with a lower level of education. We also proved statistically significant relationships between the average monthly spend on sports activities and employment. Employed respondents and entrepreneurs invested more in sports activities than pensioners and disabled pensioners.

This research also proved statistically significant relationships between the average monthly spend on sports activities and marital status. According to the research results, single respondents invested more in sports activities than the widowed, which could be a consequence of the constant population change. This information is very valuable for medical workers. They can use it in practice to make health consulting regarding correct preventative physical activities more efficient. Contemporarily, the conclusions of this research point out the necessity of an individual approach in establishing practical recommendations, especially in relation to education, employment and marital status.

\section{Acknowledgements}

Supported by the Ministry of Health of the Czech Republic, grant no. 15-31000A. All rights reserved.

\section{Conflict of interests}

The authors have no conflict of interests to declare. 


\section{Finanční prostředky občanů České republiky vynakládané do sportovních aktivit v kontextu prevence a léčby kardiovaskulárních onemocnění}

\section{Souhrn}

Sportovní aktivity nepochybně patři mezi významné faktory, kterými lze ovlivnit u jedinců vznik a rozvoj kardiovaskulárních onemocnění. Cílem tohoto příspěvku bylo zjistit, popsat a vyhodnotit souvislosti výše finančních prostředků vynakládaných občany ČR do sportovních aktivit v kontextu prevence a léčby kardiovaskulárních onemocnění v relaci se vzděláním, zaměstnáním a rodinným stavem respondentů. Výzkum byl realizován s využitím kvantitativní výzkumné strategie, pomocí nestandardizovaného dotazníku. Výzkumný výběrový soubor složený z 1992 občanů ČR (937 mužů a 1055 žen) svou strukturou odpovídal složení všech občanů ČR a vykazuje znaky reprezentativnosti z hlediska regionů (krajů), pohlaví a věku. Výsledky výzkumu prokázaly statisticky významné souvislosti mezi výší finančních prostředků vynakládaných obyvateli České republiky v průměru za měsíc do sportovních aktivit v kontextu prevence a léčby kardiovaskulárních onemocnění ve všech vybraných souvislostech. V souvislosti se vzděláním více do sportovních aktivit investují respondenti s vyšším, zejména pak vysokoškolským vzděláním, méně občané se základním vzděláním či vyučení. Ve vztahu k zaměstnání více do sportovních aktivit investují občané v zaměstnaneckém poměru a podnikatelé, méně naopak starobní a invalidní důchodci. V relaci s rodinným stavem více do sportovních aktivit investují svobodní, méně ovdovělí, což může být následkem i toho, že v České republice dochází ke změně struktury obyvatelstva. Tato zjištění poskytují zdravotnickým pracovníkům cenné informace prakticky využitelné pro zefektivnění zdravotního poradenství v oblasti vhodných pohybových aktivit v rámci jednotlivých úrovní prevence kardiovaskulárních onemocnění a zároveň poukazují na nutnost individuálního přístupu při sestavování praktických doporučení zejména ve vazbě na vzdělání, zaměstnání i rodinný stav jedinců.

Klíčová slova: finanční prostředky; kardiovaskulární onemocnění; rodinný stav; sportovní aktivity; vzdělání; zaměstnání

\section{References}

1. Antošová D, Beneš Č, Csémy L, Částková J, Fabiánová K, Filipová V, et al. (2014). Zpráva o zdraví obyvatel České republiky. Praha: Ministerstvo zdravotnictví ČR.

2. Centers for Disease Control and Prevention (2018). Workplace health promotion. [online] [cit. 2018-08-24]. Available from: https://www.cdc.gov/chronicdisease/resources/publications/ aag/workplace-health.htm

3. Czech National Bank (2018). Central bank exchange rate fixing. [online] [cit. 2018-07-22]. Available from: https://www.cnb.cz/ en/financial-markets/foreign-exchange-market/central-bankexchange-rate-fixing/central-bank-exchange-rate-fixing/

4. Czech Statistical Office (2016a). Percentage of employees by gross monthly earnings band and by educational attainment. [online] [cit. 2018-08-24]. Available from https://www.czso.cz/ documents/10180/45379596/11002617A15.pdf/33fee21322b5-462a-a452-ca0e61c5787e?version $=1.2$

5. Czech Statistical Office (2016b). Průměrná výše starobního důchodu v České republice. [online] [cit. 2018-08-24]. Available from: https://www.czso.cz/csu/czso/cr_od_roku_1989_duchod

6. Czech Statistical Office (2016c). Average wages - 4. quarter of 2016. [online] [cit. 2018-08-24]. Available from: https://www. czso.cz/csu/czso/cri/prumerne-mzdy-4-ctvrtleti-2016

7. Czech Statistical Office (2018a). Aktuální populační vývoj v kostce. [online] [cit. 2018-08-24]. Available from: https:// www.czso.cz/csu/czso/aktualni-populacni-vyvoj-v-kostce

8. Czech Statistical Office (2018b). Economic results of health insurance companies - 4th quarter of 2017. [online] [cit. 2018-08-23]. Available from: https://www.czso.cz/csu/czso/ economic-results-of-health-insurance-companies-4-quarterof-2017

9. Česko v datech (2018). Česko na nemocenské. [online] [cit. 2018-08-24]. Available from: http://www.ceskovdatech.cz/ clanek/83-cesko-na-nemocenske/

10. Dunn AL, Marcus BH, Kampert JB, Garcia ME, Kohl HW, Blair SN (1997). Reduction in cardiovascular disease risk factors: 6-month results from Project Active. Prev Med 26(6): 883-892. DOI: 10.1006/pmed.1997.0218.

11. European Heart Health Charter. Evropská Charta pro zdraví a srdce. [online] [cit. 2018-08-23]. Available from: http://www. heartcharter.org/download/EHHC_Czech.pdf
12. Global Health Data Exchange (2017). [online] [cit. 2018-08-23]. Available from: http://ghdx.healthdata.org/gbd-results-tool

13. Hull EE, Rofey DL, Robertson RJ, Nagle EF, Otto AD, Aaron DJ (2010). Influence of marriage and parenthood on physical activity: A 2-year prospective analysis. J Phys Act Health 7(5): 577-583.

14. Chaloupka V, Elbl L, Nehyba S, Tomášková I (2003). Pohybová aktivita u nemocných s kardiovaskulárním onemocněním. Kardiologická revue 1: 16-20.

15. Komise evropských společenství (2007). Bílá kniha. Společně pro zdraví: strategický přístup pro EU na období 2008-2013. [online] [cit. 2018-08-23]. Available from: https://www. euroskop.cz/gallery/96/29011-spolecne_pro_zdravi.pdf

16. Levin-Zamir D, Baron-Epel OB, Cohen V, Elhayany A (2016). The association of health literacy with health behavior, socioeconomic indicators, and self-assessed health from a national adult survey in Israel. J Health Commun 21(2): 61-68. DOI: 10.1080/10810730.2016.1207115.

17. Linhart A (2016). Sport a riziko kardiovaskulárních onemocnění. Medical Tribune CZ. [online] [cit. 2018-08-23]. Available from: https://www.tribune.cz/clanek/39165-sport-ariziko-kardiovaskularnich-onemocneni

18. Machová J, Kubátová D, et al. (2016). Výchova ke zdraví. Praha: Grada.

19. Makris GC, Lattimer CR, Lavida, Geroulakos G (2012). Availability of supervised exercise programs and the role of structured home-based exercise in peripheral arterial disease. Eur J Vasc Endovasc Surg 44(6): 569-575. DOI: 10.1016/j. ejvs.2012.09.009.

20. Medical Statistics (2016). Hospitalizovaní v nemocnicích v ČR 2015. Praha: IHIS CR.

21. Medical Statistics (2017). Zdravotnická ročenka České republiky 2016. Praha: IHIS CR.

22. National Institute for Health and Care Excellence (2017). Prevention of Cardiovascular Disease [online] [cit. 2018-11-29]. Available from: http://www.nice.org.uk/guidance/PH25

23. National Institute of Public Health (2017). Zdravější životní styl. [online] [cit. 2018-11-29]. Available from: http://www.szu. cz/tema/podpora-zdravi/zdravejsi-zivotni-styl

24. OECD/European Observatory on Health Systems and Policies (2017). Česká republika: zdravotní profil země 2017, State of Health in the EU. Brussels: OECD Publishing, Paris/ European Observatory on Health Systems and Policies. DOI: $10.1787 / 9789264285125$-cs 
25. Olišarová V, Šedová L, Tothová V, Bártlová S, Chloubová I, Michálková H, et al. (2016). Areas of health-education of physicians and nurses in care for cardiac patients from the perspective of citizens of the Czech Republic. Neuro Endocrinol Lett 37(Suppl 2): 5-10.

26. Paffenbarger RS, Wing AL, Hyde RT (1978). Physical activity as an index of heart attack risk in college alumni. Am J Epidemiol 108(3): 161-175. DOI: 10.1093/oxfordjournals.aje.a112608.

27. Piepoli MF, Hoes AW, Agewall S, Albus C, Brotons C, Catapano AL, et al. (2016). European guidelines on cardiovascular disease prevention in clinical practice: the sixth joint task force of the european society of cardiology and other societies on cardiovascular disease prevention in clinical practice (constituted by representatives of 10 societies and by invited experts). Developed with the special contribution of the European Association for Cardiovascular Prevention \& Rehabilitation (EACPR). Eur Heart J 37(29): 2315-2381. DOI: 10.1093/eurheartj/ehw106.

28. Pina IL, Apstein CS, Balady GJ, Belardinelli R, Chaitman BR, Duscha BD (2003). Exercise and heart failure: a statement from the American Heart Association Committee on exercise, rehabilitation, and prevention. Circulation 107(8): 1210-1225.

29. Pirnerová D (2017). Srdci svědčí pohyb [online] [cit. 2018-1129]. Available from: http://www.mesicnikzdravi.cz/200403/ srdci.htm

30. Revue pro sociální politiku a výzkum (2018). Zdravotní profil České republiky 2017. [online] [cit. 2018-08-23]. Available from: https://socialnipolitika.eu/2018/03/zdravotni-profilceske-republiky-2017
31. Rosolová H et al. (2013). Preventivní kardiologie v kostce. Praha: Axonite.

32. Řezníčková A (2018). Češi se s výdaji za sport vejdou pod 5 tisíc ročně, nejdražší je lyžování. iDNES.cz. [online] [cit. 2018-0823]. Available from: https://ekonomika.idnes.cz/utracenicechu-za-sport-vydaje-lyzovani-beh-plavani-cyklistika-psj-/ ekonomika.aspx?c=A180628_112435_ekonomika_are

33. Sattelmair J, Pertman J, Ding EL, Kohl HW, Haskell W, Lee IM (2011). Dose response between physical activity and risk of coronary heart disease: a meta-analysis. Circulation 124(7): 789-795. DOI: 10.1161/CIRCULATIONAHA.110.010710.

34. Schoeppe S, Vandelanotte C, Rebar AL, Hayman M, Duncan MJ, Alley SJ (2018). Do singles or couples live healthier lifestyles? Trends in Queensland between 2005-2014. PLoS ONE 13(2): e0192584. DOI: 10.1371/journal.pone.0192584.

35. Spencer RM, Heidecker B, Ganz P (2016). Behavioral cardiovascular risk factors - effect of physical activity and cardiorespiratory fitness on cardiovascular outcomes. Circ J 80(1): 34-43. DOI: 10.1253/circj.CJ-15-1159.

36. Tully MA, Cupples ME, Chan WS, McGlade K, Young IS (2005). Brisk walking, fitness, and cardiovascular risk: A randomized controlled trial in primary care. Prev Med 41(2): 622-628. DOI: 10.1016/j.ypmed.2004.11.030.

37. WHO (2007). Prevention of cardiovascular disease. Geneva: WHO. 